\title{
The effects of dietary Eleutherine bulbosa on the growth, leukocyte profile, and digestive enzyme activity of the striped catfish Pangasianodon hypophthalmus
}

\author{
RUDY AGUNG NUGROHO ${ }^{1, \vartheta}$, MEYLIANAWATI ${ }^{1}$, ODETA FEBRI ASOKAWATI ${ }^{1}$, YANTI PUSPITA SARI ${ }^{1}$, \\ ESTI HANDAYANI HARDI ${ }^{2}$ \\ ${ }^{1}$ Laboratory of Animal Physiology, Development, and Molecular, Department of Biology, Faculty of Mathematics and Natural Sciences, Universitas \\ Mulawarman. J1. Barong Tongkok No. 4, Gunung Kelua, Samarinda 75123, East Kalimantan, Indonesia. Tel.: +62-541-749140, `email \\ rudyagung.nugroho@fmipa.unmul.ac.id, rudysatriana@yahoo.com \\ ${ }^{2}$ Microbiology Laboratory, Department of Aquaculture, Faculty of Fisheries and Marine Science, Universitas Mulawarman. Samarinda 75123, \\ East Kalimantan, Indonesia.
}

Manuscript received: 8 January 2018. Revision accepted: 21 February 2018.

\begin{abstract}
Nugroho RA, Meylianawati, Asokawati OF, Sari YP, Hardi EH. 2018. The effects of dietary Eleutherine bulbosa on the growth, leukocyte profile, and digestive enzymes activity of Pangasianodon hypophthalmus. Nusantara Bioscience 10: 47-52. This study was conducted to examine the effects of Eleutherine bulbosa (Mill.) Urb extract (EAE) on the average weekly gain (AWG), specific growth rate (SGR), feed efficiency (FE), digestive enzyme (amylase, lipase, protease) activity, total and differential leukocyte counts, and phagocytosis activity of the striped catfish (Pangasianodon hypophthalmus). Four groups of fish with three replicates were fed 15 (P1), $30(\mathrm{P} 2), 45(\mathrm{P} 3)$, and $60(\mathrm{P} 4) \mathrm{g} \mathrm{kg}^{-1}$ of EAE in a basal diet and compared with control (C) fish without EAE at a rate $3 \%$ of body weight for 4 weeks. At the end of the trial, the results showed that fish fed EAE above $15 \mathrm{~g} \mathrm{~kg}^{-1}$ in the diet significantly increased AWG, while SGR, FE, lipase, protease, and neutrophil, and lymphocyte activity were not affected by any dietary concentration of EAE. The diet containing $45 \mathrm{~g} \mathrm{~kg}^{-1}$ EAE increased amylase activity in the fish while the highest number of leukocytes and phagocytosis activity was found in the fish fed $30 \mathrm{~g} \mathrm{~kg}^{-1}$ EAE in the diet. These findings suggest that the inclusion of EAE in the diet, in amounts higher than $30 \mathrm{~g} \mathrm{~kg}^{-1}$, is beneficial in improving amylase, leukocyte and phagocytosis activity of fish.
\end{abstract}

Keywords: Digestive enzymes, Eleutherine bulbosa, growth, leukocyte profile, Pangasianodon hypophthalmus

Abbreviations: AWG: Average weekly gain, CBI: Centrum tot Bevordering van de Import uit ontwikkelingslanden, DO: Dissolved oxygen, EAE: Eleutherine bulbosa (Mill.) Urb extract, FE: Feed efficiency, IL-2: Interleukin 2, INFy: Interferon gamma, SGR: Specific growth rate, Th-1: Type $1 \mathrm{~T}$ helper

\section{INTRODUCTION}

As fish consumption demand continues to grow worldwide, new strategies to increase aquaculture productivity need to be developed. Research is required into eco-friendly feed production strategies to assist aquaculturists reduce operating costs of cultivating fish such as the striped catfish (Pangasianodon hypophthalmus Sauvage, 1878). Striped catfish are produced mainly in Asian countries (Phan et al. 2009). According to CBI (2015), Vietnam is the main Pangasianodon producer, followed by Indonesia. In Indonesia production is reported to reach 400,000 tons per year, much of it for domestic consumption, but the fish has also been widely exported from Indonesia to various countries in Europe due to the acceptability of the product and its low price (Ciardullo et al. 2008; Guimarães et al. 2016). The success and significant increase in striped catfish production have received attention not only from farmers and investors but also from researchers seeking to increase productivity through strategies to improve growth rates, health performance, and the immune system of the fish.
The potential of feed additives such as immunostimulants, and phytobiotics from particular plantbased feedstuffs to improve fish productivity and health is gaining momentum (Citarasu 2010; Van Hai 2015; Devi et al. 2016; Hernández et al. 2016). One such herbal plant, namely Eleutherine bulbosa (Mill.) Urb, is found worldwide, particularly in southern Africa, in rubber plantations in Java, and in Kalimantan Island, Indonesia. The plant belongs to the Iridaceae family and is cultivated in China for ornamental and medicinal purposes. It is used as a traditional carminative in its pure form, and together with galangal, is used to treat cold and nasal congestion in children (Saralamp et al. 1996; Ifesan et al. 2009). The bulb of E. bulbosa has been known by local tribes in Kalimantan not only as a folk medicine but also as a natural antioxidant and color enhancer of meat products. The bulb is also used for enhancing breast-milk production, and to treat cardiac disease, breast cancer, stroke, hypertension, and sexual disorders (Ieyama et al. 2011; Insanu et al. 2014).

Previous research has been carried out to evaluate the feasibility of using herbal plants in aquaculture (Chakrabarti 2005; Citarasu 2010; Thanikachalam et al. 
2010; Chakraborty et al. 2014; Van Hai 2015). Various physiological tools have been used to evaluate effects of feedstuffs on the growth performance and health of fish. These include average weekly gain (AWG), specific growth rate (SGR) (Jiang et al. 2016); feed efficiency (FE) (Baloi et al. 2016; Hien et al. 2016); survival rate (Cai et al. 2015) applied to various fish species. Immunephysiological responses such as alteration of total leukocyte and differential leukocyte counts (Adel et al. 2015), phagocytosis activity (Bennani et al. 1995; Haugland et al. 2012; Chi et al. 2016) and digestive enzyme activity (Jiang et al. 2015; Abidin et al. 2016; Couto et al. 2016) have been also successfully used as indicators of the immune and health status of several fish species. However, such information regarding the effects of E. bulbosa bulbs extract (EAE) on striped catfish is limited. Thus, the study reported here aimed to evaluate the effects of various concentration of dietary EAE supplementation on the growth, survival, immunity and digestive enzyme activity of the catfish under laboratory conditions.

\section{MATERIALS AND METHODS}

\section{Study area}

The study was conducted in the Animal Physiology, Development, and Molecular Laboratory, Department of Biology, Faculty of Mathematics and Natural Sciences, Mulawarman University, Samarinda, East Kalimantan, Indonesia.

\section{Plant materials}

The Eleutherine bulbosa dried cut bulbs were purchased from a local market in Samarinda, East Kalimantan, Indonesia. The identity of the bulb samples was confirmed by an expert researcher (Department of Biology), Mulawarman University, East Kalimantan, Indonesia. To eliminate extraneous matter, the collected $E$. bulbosa bulbs were washed with deionized water and immediately dried in an oven at $40^{\circ} \mathrm{C}$ for $12 \mathrm{~h}$. Dry $E$. bulbosa was crushed and sieved to make powder. The powder was extracted with $95 \%$ ethanol for 7 days (100 g $\left.\mathrm{L}^{-1}\right)$. After filtration, the extract was evaporated by using a rotary evaporator and stored at $4^{\circ} \mathrm{C}$ until used as a crude extract.

\section{Preparation of basal and test diet}

A basal fish diet was bought from a commercial factory (Hi Pro Vite ${ }^{\circledR}$ FF-888). It contained $36-38 \%$ protein, $2 \%$ lipid, $2 \%$ crude fiber, $10 \%$ ash dan $12 \%$ moisture. The test diets were prepared by mixing the basal diet with various concentration of $\operatorname{EAE}\left(15 ; 30 ; 45\right.$, and $\left.60 \mathrm{~g} \mathrm{~kg}^{-1}\right)$, by pelletizing the mixes using a mincer $(0.5 \mathrm{~mm}$ diameter, 1 $\mathrm{mm}$ length pellets), and then by drying under direct sunlight. The dried pellets were then allowed to cool at room temperature, packed and stored in a dark room before being used as test diets or a control-basal diet (i.e., without EAE addition).

\section{Animals and experimental setup}

Two hundred fish (average initial weight $16.62 \mathrm{~g}$ ), 50 days old, were purchased from a local breeding farm, in Samarinda East Kalimantan and acclimated at the Animal Physiology, Development, and Molecular Laboratory, Mulawarman University, East Kalimantan for a week. Fish were then randomly distributed into six triplicate groups, with ten fish in each group. Each group of fish was then placed in a plastic tank. For 4 weeks, fish in each group were fed with various concentrations of EAE viz 15; 30; 45 , and $60 \mathrm{~g} \mathrm{~kg}^{-1}$ feed supplementation. Temperature, $\mathrm{pH}$, and Dissolve Oxygen (DO) were measured every secondday using routine thermometer, $\mathrm{pH}$ meter, and $\mathrm{HM}-7 \mathrm{~J} \mathrm{pH}$ instrument (DKK-TOA $\AA$, Japan). The fish in each plastic tank were fed with basal diet or treatment diets at a rate of $3 \%$ of body weight three times per day. Uneaten food and feces were siphoned out before renewing the water.

\section{Growth indices}

For measuring individual fish weights, an electronic balance (GX-4000, A\&D Co Ltd., Japan) was used. Both initial weight (Wo) and final weight (Wt) of fish were used to calculate average weekly gain (AWG), specific growth rate (SGR), and feed efficiency (FE) as follows:

$$
\begin{aligned}
& \operatorname{AWG}\left(\mathrm{g} \mathrm{week}^{-1}\right)=(\mathrm{Wt}-\mathrm{Wo}) / \mathrm{Wk} \\
& \operatorname{SGR}(\% \text { body weight. gain/day })=\left[\frac{\mathrm{Ln}(\mathrm{Wt})-\mathrm{Ln}(\mathrm{Wo})}{\mathrm{Wk}}\right] \\
& \operatorname{FE}(\%)=\left[\frac{\mathrm{W}_{\mathrm{t}}-\mathrm{W}_{0}}{\mathrm{~F}}\right] \times 100 \%
\end{aligned}
$$

Where Wt is the final weight $(\mathrm{g})$ and Wo is the weight ( $g$ ) of the fish at the commencement of the growth period, respectively, and $\mathrm{Wk}$ is the number of weeks during the growth period, $\mathrm{F}=$ The amount of feed given $(\mathrm{g})$.

\section{Total and differential leukocyte count}

At the end of week 4, blood samples were taken by caudal venipuncture after anesthetizing the fish. Total leukocyte $\left(10^{3}\right.$ per $\left.\mathrm{mm}^{3}\right)$ was determined manually with the improved Neubauer counting chamber. The percentage of neutrophils, lymphocytes, and monocytes were determined by using an Auto Hematology Analyser Mindray BC2800, Mindray® Shenzhen, China.

\section{Phagocytosis activity}

The phagocytic activity assay was determined by the following modified method of Subeenabegum and Navaraj (2016) and Michael et al. (1998):

Phagocytosis activity $(\%)=\frac{\text { Phagocytosis leukocyte number }}{\text { Observed total leukocyte number }} \times 100$

\section{Digestive enzymes activity}

To evaluate the effects of EAE on the activities of digestive enzymes (amylase, protease, and lipase), digestive tracts of fish from each culture tank were sampled at the end of the experiment, and crude amylase and protease were extracted (Nugroho and Fotedar 2015).The 
digestive tract of each fish was homogenized and placed in ice in $5 \mathrm{~mL} 0.1 \mathrm{M}$ citrate-phosphate buffer $(\mathrm{pH} \mathrm{5.5)}$. The resulting homogenates were then centrifuged at $45009 \mathrm{~g}$ for 5 min using Eppendorf centrifuge allegraTM $\mathrm{X}-22 \mathrm{R}$ (Beckman Coulter, Inc., US) and the supernatants (solution) were used directly for enzyme assays. Amylase activity was assessed following the methods proposed by Bernfeld (1955); Biesiot and Capuzzo (1990). Amylase activity (unit activity) in solution was assayed based on maltose liberated per mg protein per hour using soluble starch $\left(15 \mathrm{mg} \mathrm{mL}^{-1}\right)$ as substrate in $0.1 \mathrm{M}$ phosphate buffer (pH 6.5) with $0.05 \mathrm{M} \mathrm{NaCl}$ at $37^{\circ} \mathrm{C}$. Meanwhile, protease activity was measured according to the Bergmeyer (2012) protocol. One unit enzyme activity was defined as the amount of enzyme that yielded the equivalent of 1-mole tyrosine/minute. The protein content in solution was assayed using the Folin phenol method, and bovine serum albumin was used as a standard for protein determination (Hartree 1972). Lipase activity was performed following the method of Linfield et al. (1984). One unit of lipase per $\mathrm{mL}\left(\mathrm{U} \mathrm{mL}^{-1}\right)$ is defined as $1 \mu \mathrm{mol}$ of fatty acid liberated per minute.

\section{Statistical analysis}

Results are expressed as means \pm standard error (SE) and data were analyzed using SPSS version 22 (SPSS, Inc., USA). The data for percentage of total leukocytes, and of neutrophils, lymphocytes and monocytes, and for the digestive enzyme activity (amylase, lipase, protease) at the end of the week 4, were subjected to one way ANOVA, followed by Duncan post hoc test to evaluate the significance of differences among the group of treatments. All significance tests were at $P<0.05$ levels.

\section{RESULTS AND DISCUSSION}

\section{Growth indices and hematological profiles}

Growth indices, feeding efficiency, and the hematology profile of the fish fed five different diets are presented in Table 1. After 4 weeks of feeding, 30-60 $\mathrm{g} \mathrm{kg}^{-1}$ EAE included in the diet had positive effects on the final fish weight and AWG with value range of 49.86-51.50 g and 8.53-8.69 g/wk, respectively. No significant effect on the SGR (3.16-3.83 \% per day) and FE (67.38-75.69\%) was shown by fish fed four different test diets. In the present study, the highest number of leukocytes $\left(38.7510^{6}\right.$ per $\mathrm{mm}^{3}$ ) was found in fish fed $60 \mathrm{~g} \mathrm{~kg}^{-1}$ EAE. However, the percentage of neutrophils for fish fed any concentration of EAE was not significantly different from the control group. Furthermore, monocyte $\%$, and phagocytosis activity were not affected by any dietary concentration of EAE.

\section{Digestive enzymes activity}

The improvement of growth indices and hematoimmunological profile of fish are closely related to the digestive enzyme activity which in turn leads to breakdown of large biomolecules into small absorbable nutrient molecules in the intestines of the fish (Cho 1987; Kumar et al. 2015). Our results showed that dietary inclusion of EAE increased digestive enzyme activities of $P$. hypophthalmus. There was significantly higher amylase, and lipase activity in fish fed EAE at levels higher than $30 \mathrm{~g} \mathrm{~kg}^{-1}$ in the diet (Figure 1).

\section{Discussion}

The efficacy of phytochemicals as growth promoters and immunomodulators in the diets of various fish species has been well documented. It has been reported that dietary supplementation with thyme (Thymus vulgaris) and vitamin E resulted in an improvement in growth performance and fed efficiency of juvenile Acipenser stellatus (Goda 2008). Dorojan et al. (2015) also reported that fish fed diets containing at least $200 \mathrm{mg} \mathrm{kg}^{-1}$ of ginseng herb (Ginsana ${ }^{\circledR}$ G115) for 17 weeks, had enhanced growth performance, feed efficiency, and hematological indices. Similar results concerning the effect of a commercial source of Yucca schidigera and Quillaja saponaria extracts (Nutrafito Plus $\left.{ }^{\circledR}\right)$, in practical diets, on striped catfish $P$. hypophthalmus growth, feed utilization, and hematological parameters have also been reported by Guroy et al. (2016).

Table1. Mean \pm standard error (SE) of growth parameters and leukocyte profile of Pangasianodon hypophthalmus fed various concentrations of Eleutherine bulbosa extract in the diet for 4 weeks

\begin{tabular}{lccccc}
\hline \multirow{2}{*}{ Parameters } & \multicolumn{5}{c}{ Groups } \\
\cline { 2 - 6 } & C & P1 & P2 & P3 & P4 \\
\hline Initial weight (g) & $16.21 \pm 0.40^{\mathrm{a}}$ & $15.35 \pm 0.54^{\mathrm{a}}$ & $16.72 \pm 0.82^{\mathrm{a}}$ & $16.81 \pm 0.52^{\mathrm{a}}$ & $15.71 \pm 0.44^{\mathrm{a}}$ \\
Final weight (g) & $32.72 \pm 1.37^{\mathrm{a}}$ & $40.01 \pm 3.24^{\mathrm{a}}$ & $51.50 \pm 4.63^{\mathrm{b}}$ & $51.44 \pm 3.83^{\mathrm{b}}$ & $49.86 \pm 2.99^{\mathrm{b}}$ \\
AWG (g/wk) & $4.12 \pm 0.03^{\mathrm{a}}$ & $6.16 \pm 0.85^{\mathrm{a}}$ & $8.69 \pm 1.19^{\mathrm{b}}$ & $8.65 \pm 1.01^{\mathrm{b}}$ & $8.53 \pm 0.71^{\mathrm{b}}$ \\
SGR (\% body weigh /day) & $2.33 \pm 0.15^{\mathrm{a}}$ & $3.16 \pm 0.30^{\mathrm{b}}$ & $3.71 \pm 0.36^{\mathrm{b}}$ & $3.69 \pm 0.30^{\mathrm{b}}$ & $3.83 \pm 0.18^{\mathrm{b}}$ \\
FE (\%) & $55.68 \pm 0.01^{\mathrm{a}}$ & $67.38 \pm 3.84^{\mathrm{b}}$ & $73.71 \pm 4.36^{\mathrm{b}}$ & $73.80 \pm 3.70^{\mathrm{b}}$ & $75.69 \pm 2.02^{\mathrm{b}}$ \\
& & & & \\
Leukocyte (10 per mm $\left.{ }^{3}\right)$ & $22.61 \pm 1.47^{\mathrm{a}}$ & $18.45 \pm 1.11^{\mathrm{a}}$ & $16.05 \pm 0.36^{\mathrm{ab}}$ & $14.93 \pm 0.91^{\mathrm{ab}}$ & $38.75 \pm 2.31^{\mathrm{c}}$ \\
Neutrophile (\%) & $7.00 \pm 0.57^{\mathrm{a}}$ & $6.33 \pm 0.33^{\mathrm{a}}$ & $6.00 \pm 0.57^{\mathrm{a}}$ & $6.00 \pm 0.57^{\mathrm{a}}$ & $7.00 \pm 0.57^{\mathrm{a}}$ \\
Limphocyte (\%) & $72.33 \pm 2.18^{\mathrm{a}}$ & $68.66 \pm 0.88^{\mathrm{ab}}$ & $69.00 \pm 0.57^{\mathrm{ab}}$ & $67.33 \pm 1.45^{\mathrm{b}}$ & $67.00 \pm 1.15^{\mathrm{b}}$ \\
Monocyte (\%) & $20.66 \pm 2.27^{\mathrm{a}}$ & $27.33 \pm 1.20^{\mathrm{b}}$ & $25.00 \pm 0.57^{\mathrm{b}}$ & $26.66 \pm 0.88^{\mathrm{b}}$ & $26.00 \pm 1.52^{\mathrm{b}}$ \\
Phagosytosis activity (\%) & $76.67 \pm 2.84^{\mathrm{a}}$ & $58.00 \pm 2.51^{\mathrm{b}}$ & $64.67 \pm 2.40^{\mathrm{b}}$ & $60.33 \pm 2.84^{\mathrm{b}}$ & $68.33 \pm 4.04^{\mathrm{b}}$ \\
\hline
\end{tabular}

Note: Means in the same row having different superscript letters $(\mathrm{a}, \mathrm{b}, \mathrm{c})$ indicate significant differences $(P<0.05)$. $\mathrm{C}=$ control gorup $\mathrm{P} 1=15 \mathrm{~g} \mathrm{~kg}^{-1} ; \mathrm{P} 2=30 \mathrm{~g} \mathrm{~kg}^{-1} ; \mathrm{P} 3=45 \mathrm{~g} \mathrm{~kg}^{-1 ;} \mathrm{P} 4=60 \mathrm{~g} \mathrm{~kg}^{-1}$. AWG $=$ average weekly gain, $\mathrm{SGR}=$ specific growth rate, $\mathrm{FE}=$ feed efficiency 


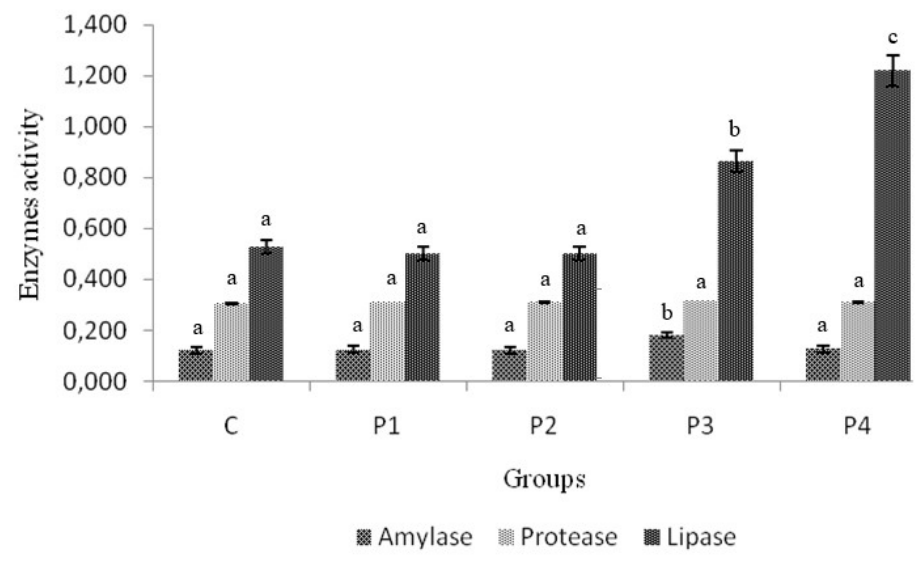

Figure 1. Digestive enzymes (Amylase, Protease, and Lipase) activity of Pangasianodon hypophthalmus fed various concentration of Eleutherine bulbosa extract for 30 days. Letters $(\mathrm{a}, \mathrm{b}, \mathrm{c})$ indicated significant differences $(P<0.05) . \mathrm{C}=$ control groups $\mathrm{P} 1=15 ; \mathrm{P} 2=30$; $\mathrm{P} 3=45 ; \mathrm{P} 4=60 \mathrm{~g} \mathrm{~kg}^{-1}$. Amylase activity (unit activity) in solution was assayed based on maltose liberated per mg protein per hour using soluble starch $\left(15 \mathrm{mg} \mathrm{mL}^{-1}\right)$ as substrate in $0.1 \mathrm{M}$ phosphate buffer $(\mathrm{pH} 6.5)$ with $0.05 \mathrm{M} \mathrm{NaCl}$ at $37^{\circ} \mathrm{C}$. One unit enzyme activity was defined as the amount enzyme that yielded the equivalent of 1-mole tyrosine per minute. One unit lipase per $\mathrm{mL}^{(}\left(\mathrm{U} \mathrm{mL}^{-1}\right)$ defined as 1 $\mu \mathrm{mol}$ of fatty acid liberated per minute

However, the current study was conducted to examine effects of Eleutherine bulbosa extract (EAE) on the growth and feed utilization of fish. This had not previously been researched. According to the best of our knowledge, the present study is the first to document the effects of dietary EAE supplementation on growth performance, feed utilization efficiency and hematological profile in Pangasianodon hypophthalmus.

Previous research reported that there are three main groups of bioactive compounds that have been isolated from $E$. bulbosa; namely naphthalene, naphthoquinones, and anthraquinone (Insanu et al. 2014). Liu et al. (2010) and Kumar et al. (2015) revealed that the dietary anthraquinone augmented weight gain and feed efficiency in the freshwater prawn species Macrobrachium rosenbergii, and also improved growth indices and total leukocyte count in fingerlings of the carp, Cirrhinus mrigala. In this current study, we found that the supplementation of the diet with extracts of the bulb Pangasianodon hypophthalmus (EAE) enhanced final weight and AWG of the fish. This result is in line with the findings of Xie et al. (2008) and Babak et al. (2012) showing that fish (Rutilus frisii) supplemented with $0.5 \%$ $2.0 \%$ anthraquinone extract from Rheum palmatum had significantly enhanced growth.

In this current study, EAE supplementation in the diet of $P$. hypophthalmus, besides increasing the growth performance of the fish also resulted in augmented hematoimmuno competence. The highest leukocyte counts observed in the P4 group fed with $60 \mathrm{~g} \mathrm{~kg}^{-1}$ EAE supplementation might be due to the immune-boosting properties of anthraquinone that can be found in the EAE. This study is in agreement with the previous finding of Kumar et al. (2015) who reported that dietary anthraquinone, at a $1 \%$ incorporation level, augmented hematological parameters. Hematological parameters such as total leukocyte counts, and lymphocyte, neutrophil and monocyte counts are pivotal in assessing the physiological condition of fish. Total leukocytes, as well as the component neutrophil, lymphocyte, and monocyte counts, are used as an indicator of the hematological status of fish in relation to innate immune defenses and regulation of immunological function in the fish (Ballarin et al. 2004).

Though the underlying mechanism(s) whereby EAE boosts the haematological indices of $P$. hypophthalmus is not properly understood, nevertheless, Nair et al. (2002) and Lyu and Park (2005) have suggested that flavonoid plant metabolites in the bulbs of E. americana (Kuntorini et al. 2016) may contribute to promoting cellular immunity by modulating Th-1 derived cytokines such as IL-2 (Interleukin 2) and INFy (Interferon). Flavonoids found in the EAE may be biocatalysts in the production of leukocytes and in stimulating nonspecific cellular immunity by leukocytes.

Plant tissues also contain various substances that may modify the activity of enzymes (Kuz'mina 2014). For example, an increase in digestive enzyme activity could be responsible for enhanced nutrient utilization and better final weight and AWG in fish supplemented with EAE. In our study, the high amylase activity exhibited in fish fed 45 $\mathrm{g} \mathrm{kg}^{-1}$ EAE in the diet, was probably due to active compounds in EAE that stimulate digestive tract activity. Such stimulation reduces the time for food to pass through the digestive tract (Platel and Srinivasan 2000). Nevertheless, an increase in dietary EAE from 45 to $60 \mathrm{~g}$ $\mathrm{kg}^{-1}$ in our study resulted in a reduction in amylase activity in fish. This result is perhaps supported by the study of Ieyama et al. (2011) who found that aqueous methanolsoluble extracts of E. bulbosa bulbs showed potent inhibitory activity that suppressed carbohydrate digestion. This inhibition was due to an active compound in the bulb of E. bulbosa, namely eleutherinoside A, which suppresses carbohydrate digestion. 
Our present study also found that the fish fed EAE at levels higher than $30 \mathrm{~g} \mathrm{~kg}^{-1}$ in the diet showed a significantly increased lipase activity. This finding is supported by Ojha et al. (2014) who revealed that dietary supplementation with an ethanolic extract of the legume species Mucuna pruriens led to significant enhancement of intestinal lipase activity in Labeo rohita fingerlings. However, in this study, we found no significant effect of dietary EAE supplementation on the digestive protease activity of $P$. hypophthalmus. This finding is similar to previous research reporting that trypsin activity of Mesopotamichthys sharpeyi fingerling was not affected by supplementation with ginger extract (Rahimi-Yadkoori et al. 2015). Moreover, studies by Alarcón et al. (2001) found that extracts of various legume seeds significantly inhibited intestinal protease activity of yellow snapper (Lutjanus argentiventris) and dog snapper (Lutjanus novemfasciatus).

In conclusion, the current findings showed that dietary supplementation by extracts of the plant Eleutherine bulbosa at levels higher than $30 \mathrm{~g} \mathrm{~kg}^{-1}$ in the diet is beneficial in improving growth rates, lipase activity, leukocyte, lymphocyte and monocyte counts, and phagocytosis activity of the catfish Pangasianodon hypophthalmus. However, further research needs to be conducted in order to find out the specific mechanism involved in how the EAE improves growth, hematoimmunological indices, and the digestive enzyme profile.

\section{ACKNOWLEDGEMENTS}

The authors are grateful to the Department of Biology, Faculty of Mathematics and Natural Sciences, Mulawarman University, Samarinda, East Kalimantan, Indonesia. The authors' gratitude is also extended to Firman M. Nur and Widha Prahastika who helped this research in various ways.

\section{REFERENCES}

Abidin DAZ, Hashim M, Das SK, Rahim SM, Mazlan AG. 2016 Enzymatic digestion of stomachless fish Zenarchopterus buffonis. AACL Bioflux 9: 695-703.

Adel M, Abedian Amiri A, Zorriehzahra J, Nematolahi A, Esteban MÁ. 2015. Effects of dietary peppermint (Mentha piperita) on growth performance, chemical body composition and hematological and immune parameters of fry Caspian white fish (Rutilus frisii kutum). Fish Shellfish Immunol 45: 841-847.

Alarcón F, García-Carreño F, Del Toro MN. 2001. Effect of plant protease inhibitors on digestive proteases in two fish species, Lutjanus argentiventris and L. novemfasciatus. Fish Physiol Biochem 24: 179189.

Babak N, Reza M, Ali S. 2012. Effects of anthraquinone extract from Rheum palmatum on growth indices of Rutilus frisii kutum. African J Anim Biomed Sci 7: 123-132.

Ballarin L, Dall'Oro M, Bertotto D, Libertini A, Francescon A, Barbaro A. 2004. Haematological parameters in Umbrina cirrosa (Teleostei, Sciaenidae): a comparison between diploid and triploid specimens. Comp Biochem Physiol A Mol Integr Physiol 138: 45-51.

Baloi M, de Carvalho CVA, Sterzelecki FC, Passini G, Cerqueira VR 2016. Effects of feeding frequency on growth, feed efficiency and body composition of juveniles Brazilian sardine, Sardinella brasiliensis (Steindacher 1879). Aquacult. Res 47: 554-560.
Bennani N, Schmid-Alliana A, Lafaurie M. 1995. Evaluation of phagocytic activity in a teleost fish, Dicentrarchus labrax. Fish Shellfish Immunol 5: 237-246.

Bergmeyer H-U. 2012. Methods of Enzymatic Analysis. Elsevier, The Nederlands.

Bernfeld P. 1955. Amylases, alpha, and beta. Meth Enzymol 1: 149-158.

Biesiot PM, Capuzzo JM. 1990. Digestive protease, lipase and amylase activities in stage I larvae of the American lobster, Homarus americanus. Comp Biochem Physiol A Mol Integr Physiol 95: 47-54.

Cai Z, Li W, Mai K, Xu W, Zhang Y, Ai Q. 2015. Effects of dietary sizefractionated fish hydrolysates on growth, activities of digestive enzymes and aminotransferases and expression of some protein metabolism related genes in large yellow croaker (Larimichthys crocea) larvae. Aquaculture 440: 40-47.

CBI. 2015. CBI product factsheet: Pangasius in Europe. Ministry of Foreign Affairs, CBI Market Intelligence, Netherland.

Chakrabarti R. 2005. Stimulation of immunity in Indian major carp Catla catla with herbal feed ingredients. Fish Shellfish Immunol 18: 327334.

Chakraborty SB, Horn P, Hancz C. 2014. Application of phytochemicals as growth-promoters and endocrine modulators in fish culture. Rev Aquacult 6: 1-19.

Chi C, Giri SS, Jun JW, Kim HJ, Yun S, Kim SG, Park SC. 2016. Immunomodulatory effects of bioactive compound isolated from Dryopteris crassirhizoma on the grass carp Ctenopharyngodon idella. J Immunol Res 2016: 10.

Cho C. 1987. La energía en la nutrición de los peces. Nutricíon en Acuicultura 2: 197-243.

Ciardullo S, Aureli F, Coni E, Guandalini E, Iosi F, Raggi A, Rufo G, Cubadda F. 2008. Bioaccumulation potential of dietary arsenic, cadmium, lead, mercury, and selenium in organs and tissues of rainbow trout (Oncorhynchus mykiss) as a function of fish growth. J Agric Food Chem 56: 2442-2451.

Citarasu T. 2010. Herbal biomedicines: a new opportunity for aquaculture industry. Aquacult Intl 18: 403-414.

Couto A, Barroso C, Guerreiro I, Pousão-Ferreira P, Matos E, Peres H, Oliva-Teles A, Enes P. 2016. Carob seed germ meal in diets for meagre (Argyrosomus regius) juveniles: Growth, digestive enzymes, intermediary metabolism, liver and gut histology. Aquaculture 451: 396-404.

Devi KN, Dhayanithi NB, Kumar TTA, Balasundaram C, Harikrishnan R. 2016. In vitro and in vivo efficacy of partially purified herbal extracts against bacterial fish pathogens. Aquaculture 458: 121-133.

Dorojan OGV, Cristea V, Creţu M, Coadă M, Dediu L, Grecu IR, Plăcintă S. 2015. Effect of thyme (Thymus vulgaris) and vitamin $\mathrm{E}$ on growth performance and body composition of Acipenser stellatus juveniles. AACL Bioflux 8 (2): 195-202.

Goda AMAS. 2008. Effect of dietary ginseng herb (Ginsana ${ }^{\circledR}$ G115) supplementation on growth, feed utilization, and hematological indices of nile tilapia, Oreochromis niloticus (L.), fingerlings. J World Aquacult Soc 39: 205-214.

Guimarães CFM, Mársico ET, Monteiro MLG, Lemos M, Mano SB, Conte Junior CA. 2016. The chemical quality of frozen Vietnamese Pangasius hypophthalmus fillets. Food Sci Nutr 4: 398-408.

Güroy B, Mantoğlu S, Merrifield DL, Guroy D. 2016. Effects of dietary nutrafito plus on growth, haemotological parameters and total ammonia-nitrogen excretion of juvenile striped catfish Pangasianodon hypophthalmus. Aquacult Res 47: 1770-1777.

Hartree EF. 1972. Determination of protein: a modification of the Lowry method that gives a linear photometric response. Ann Biochem 48: $422-427$.

Haugland GT, Jakobsen RA, Vestvik N, Ulven K, Stokka L, Wergeland HI. 2012. Phagocytosis and respiratory burst activity in lumpsucker (Cyclopterus lumpus L.) leukocytes analysed by flow cytometry. PLoS ONE 7 (10): e47909. DOI: 10.1371/journal.pone.0047909.

Hernández AJ, Romero A, Gonzalez-Stegmaier R, Dantagnan P. 2016. The effects of supplemented diets with a phytopharmaceutical preparation from herbal and macroalgal origin on disease resistance in rainbow trout against Piscirickettsia salmonis. Aquaculture 454: 109117.

Hien TTT, Phu TM, Tu TLC, Tien NV, Duc PM, Bengtson DA. 2016. Effects of replacing fish meal with soya protein concentrate on growth, feed efficiency and digestibility in diets for snakehead, Channa striata. World Aquacult 5: 674-674. 
Ieyama T, Gunawan-Puteri MDPT, Kawabata J. 2011, $\alpha$-Glucosidase inhibitors from the bulb of Eleutherine americana. Food Chem 128: 308-311.

Ifesan BOT, Joycharat N, Voravuthikunchai SP. 2009. The mode of antistaphylococcal action of Eleutherine americana. FEMS Immunol Med Microbiol 57: 193-201.

Insanu M, Kusmardiyani S, Hartati R. 2014. Recent studies on phytochemicals and pharmacological effects of Eleutherine americana Merr. Procedia Chem 13: 221-228.

Jiang J, Feng L, Tang L, Liu Y, Jiang W, Zhou X. 2015. Growth rate, body composition, digestive enzymes and transaminase activities, and plasma ammonia concentration of different weight Jian carp (Cyprinus carpio var. Jian). Anim. Nutr 1: 373-377.

Jiang J, Wu X-Y, Zhou X-Q, Feng L, Liu Y, Jiang W-D, Wu P, Zhao Y. 2016. Effects of dietary curcumin supplementation on growth performance, intestinal digestive enzyme activities and antioxidant capacity of crucian carp Carassius auratus. Aquaculture 463: 174 180

Kumar S, Prakash C, Gupta SK, Chadha NK, Jain KK, Ghughuskar MM, Pandey PK. 2015. Effects of dietary anthraquinone extract on growth, metabolic and haemato-immunological responses of Cirrhinus mrigala (Hamilton, 1822) fingerlings. PNAS India Sec B: Biol. Sci: $1-10$

Kuntorini EM, Dewi M, Misrina. 2016. Anatomical structure and antioxidant activity of red bulb plant (Eleutherine americana) on different plant age. Biodiversitas 17: 229-233.

Kuz'mina V. 2014. Effect of macrophytes on the activity of digestive enzymes in fish intestinal mucosa. Inland Water Biology 7: 82-87.

Linfield WM, Barauskas RA, Sivieri L, Serota S, Stevenson RW. 1984. Enzymatic fat hydrolysis and synthesis. J Amer Oil Chem Soc 61: 191-195.

Liu B, Xie J, Ge X, Xu P, Wang A, He Y, Zhou Q, Pan L, Chen R. 2010 Effects of anthraquinone extract from Rheum officinale Bail on the growth performance and physiological responses of Macrobrachium rosenbergii under high-temperature stress. Fish Shellfish Immunol 29: 49-57.

Lyu SY, Park WB. 2005. Production of cytokine and NO by RAW 264.7 macrophages and PBMC in vitro incubation with flavonoids. Arch Pharmacal Res 28: 573-581.

Michael R, Quinn C, Venkatalakshmi S. 1998. Modulation of humoral immune response by ascorbic acid in Oreochromis mossambicus (Peters). Indian J Exp Biol 36: 1038-1040.
Nair MPN, Kandaswami C, Mahajan S, Chadha KC, Chawda R, Nair H, Kumar N, Nair RE, Schwartz SA. 2002. The flavonoid, quercetin, differentially regulates Th-1 (IFN $\gamma$ ) and Th-2 (IL4) cytokine gene expression by normal peripheral blood mononuclear cells. Biochimica et Biophysica Acta (BBA) - Mol Cell Res 1593: 29-36.

Nugroho RA, Fotedar R. 2015. Effects of dietary organic selenium on immune responses, total selenium accumulation and digestive system health of marron, Cherax cainii (Austin, 2002). Aquacult. Res 46: 1657-1667.

Ojha M, Chadha N, Saini V, Damroy S, Chandraprakash S. 2014. Effect of ethanolic extract of Mucuna pruriens on growth, metabolism and immunity of Labeo rohita (Hamilton, 1822) fingerlings. Intl J Fauna Biol Study 5: 01-09.

Phan LT, Bui TM, Nguyen TTT, Gooley GJ, Ingram BA, Nguyen HV, Nguyen PT, De Silva SS. 2009. Current status of farming practices of striped catfish, Pangasianodon hypophthalmus in the Mekong Delta, Vietnam. Aquaculture 296: 227-236.

Platel K, Srinivasan K. 2000. Influence of dietary spices and their active principles on pancreatic digestive enzymes in albino rats. Food/Nahrung 44: 42-46.

Rahimi-Yadkoori N, Zanguee N, Mousavi SM, Zakeri M. 2015. Effects of ginger (Zingiber officinale) extract on digestive enzymes and liver activity of Mesopotamichthys sharpeyi fingerlings. J Persian Gulf 6: 1-10.

Saralamp P, Chuakul W, Temsiririrkkul R, Clayton T. 1996. Medicinal Plants in Thailand. Amarin Printing and Publishing,, Bangkok.

Subeenabegum S, Navaraj P. 2016. Studies on the immunostimulatory effect of extract of Solanum trilobatum and Ocimum sanctum in Mystus keletius. Intl J Fish Aquat Res 4: 376-381.

Thanikachalam K, Kasi M, Rathinam X. 2010. Effect of garlic peel on growth, hematological parameters and disease resistance against Aeromonas hydrophila in African catfish Clarias gariepinus (Bloch) fingerlings. Asian Pac J Trop Dis 3: 614-618.

Van Hai N. 2015. The use of medicinal plants as immunostimulants in aquaculture: A review. Aquaculture 446: 88-96.

Xie J, Liu B, Zhou Q, Su Y, He Y, Pan L, Ge X, Xu P. 2008. Effects of anthraquinone extract from rhubarb Rheum officinale Bail on the crowding stress response and growth of common carp Cyprinus carpio var. Jian. Aquaculture 281: 5-11. 